\title{
PERANCANGAN ANTENA MIKROSTRIP CIRCULAR PATCH UNTUK WIFI MENGGUNAKAN CHARACTERISTIC MODE ANALYSIS (CMA)
}

\author{
Liya Yusrina Sabila*), Teguh Prakoso, dan Aghus Sofwan \\ Departemen Teknik Elektro, Universitas Diponegoro, Semarang \\ Jln. Prof. Sudharto, SH, Kampus UNDIP Tembalang, Semarang 50275, Indonesia \\ ${ }^{*}$ E-mail:sabila.rina@gmail.com
}

\begin{abstract}
Abstrak
Wi-Fi (Wireless Fidelity) merupakan sebuah teknologi yang memanfaatkan peralatan elektronik untuk bertukar data secara nirkabel. Dalam sistem komunikasi wireless bagian terpenting untuk mengoptimalkan kinerjanya adalah antena. Mikrostrip adalah salah satu jenis antena yang praktis mempunyai ukuran dan dimensi yang sederhana dan mudah difabrikasi. Pada penelitian ini dibahas bagaimana desain dan analisa antena mikrostrip dengan bentuk patch sirkular dengan spesifikasi frekuensi kerja 2,400 - 2,484 GHz menggunakan substrat FR-4 dengan ketebalan 1,6 mm dan $\varepsilon_{r}=$ 4,3. Teknik pencatuan yang digunakan adalah dengan teknik microstrip line feed. Perancangan dan simulasi antena mikrostrip dilakukan menggunakan software CST Studio Suite 2016. Antena yag dirancang juga dianalisa menggunakan Characteristic Mode Analysis (CMA). Hasil yang ditampilkan berupa grafik mode-mode arus pada modal significance. Dihasilkan sebanyak dua mode yang berhimpit untuk desain patch A pada frekuensi $3081 \mathrm{MHz}$ dan terjadi perubahan untuk desain patch B, dimana kedua mode berpisah dan bergeser, mode 1 bergeser ke frekuensi 2406 MHz sedangkan mode 2 bergeser ke frekuensi $1889 \mathrm{MHz}$. Dari antena mikrostrip yang telah difabrikasi dilakukan pengukuran beberapa nilai parameter yaitu, $S_{11}$ sebesar $-21,13 \mathrm{~dB}$, VSWR 1:1,19, rentang frekuensi 2,37 - 2,54 GHz, pola radiasi directional dan gain sebesar $2,15 \mathrm{dBi}$.
\end{abstract}

Kata kunci: Wi-Fi, antena mikrostrip, characteristic mode analysis

\begin{abstract}
Wi-Fi (Wireless Fidelity) is a technology that utilizes electronic equipment to exchange data wirelessly. In wireless communication system the most important part to optimize its performance is the antenna. Microstrip is one type of antenna that has practical size and dimensions are simple and easy to fabricate. This study discussed how to design and analyze microstrip antenna with circular patch form with working frequency specification $2.400-2.484 \mathrm{GHz}$ using FR4 substrate with thickness $1.6 \mathrm{~mm}$ and $\varepsilon_{r}=4.3$. The technique of unification used is by microstrip line feed technique. The design and simulation of microstrip antenna is done using CST Studio Suite 2016 software. The designed antennas are also analyzed using Characteristic Mode Analysis (CMA). The results are graphs of current modes on modal significance. Generated as many as two modes coincide for the patch A design at a frequency of $3081 \mathrm{MHz}$ and a change occurs for the patch B design, where both modes separate and shift, mode 1 shifts to a frequency of $2406 \mathrm{MHz}$ while mode 2 shifts to a frequency of $1889 \mathrm{MHz}$. From the microstrip antenna that has been fabricated, the measurement of some parameter values is $S_{11}-21.13 \mathrm{~dB}$, VSWR 1: 1.19, frequency range $2.37-2.54 \mathrm{GHz}$, directional radiation pattern and gain of $2.15 \mathrm{dBi}$.
\end{abstract}

Keywords: Wi-Fi, microstrip antenna, characteristic mode analysis

\section{Pendahuluan}

Perkembangan teknologi saat ini sudah begitu pesat. Salah satunya di bidang telekomunikasi. Sistem telekomunikasi yang sering digunakan saat ini yaitu sistem komunikasi nirkabel. Komunikasi nirkabel merupakan komunikasi yang dapat dilakukan tanpa harus terkoneksi dengan kabel. Komunikasi nirkabel saat ini telah banyak dimanfaaatkan, contohnya adalah Wi-Fi. Sebuah $W i-F i$ dapat menghubungkan perangkat seperti komputer pribadi, ponsel pintar atau pemutar audio digital dalam jangkauan jaringan nirkabel ke internet [1]. Dalam sistem komunikasi yang menggunakan gelombang radio seperti $W i-F i$ bagian terpenting untuk mengoptimalkan kinerjanya adalah antena [2].

Antena merupakan komponen yang sangat penting pada sistem komunikasi. Semakin berkembangnya komunikasi nirkabel, kebutuhan antena semakin bertambah. Salah satu antena yang dapat diterapkan adalah antena 
mikrostrip. Antena mikrostrip memiliki konfigurasi yang paling sederhana, terdiri dari sebuah patch pada satu sisi substrate dielektrik dan memiliki bidang ground di sisi lainnya.

Antena yang dirancang juga dapat dianalisis mengenai modal arus dari struktur peradiasi antena menggunakan teori Characteristic Mode Analysis (CMA). Dari penelitian sebelumya [3], teori Characteristic Mode Analysis (CMA) digunakan untuk mengetahui modal arus yang terjadi pada struktur peradiasi yang dirancang melalui grafik eigenvalue, modal significance dan characteristic angle pada antena.

Pada perancangan selanjutnya, akan dibuat antena mikrostrip berbentuk circular patch dengan penambahan slot di bagian bawah patch. Antena ini akan dibuat dengan bahan FR-4 dengan konstanta dielektrik 4,3 sebagai bahan substrate, sedangkan copper sebagai bahan patch dan ground. Antena Wi-Fi ini dirancang memiliki rentang frekuensi 2,400 -2,484 GHz.

\section{Metode}

\subsection{Pemodelan Menggunakan Characteristic Mode} Analysis

Pada teori Characteristic Mode Analysis (CMA) menjelaskan adanya medan listrik (E) yang menghantam badan penghantar pada permukaan (S), sehingga dapat menyebabkan arus (J) di atas permukaannya. Arus yang ada dipermukaan ini selanjutnya akan menghasilkan medan yang tersebar sehingga rumus CMA dapat didefinisikan sebagai hubungan arus $\mathrm{J}$ pada permukaan $\mathrm{S}$ bahan penghantar dengan medan listrik tangensial $\mathrm{E}^{\mathrm{i}}$. [4]

$$
[L(J)]_{\text {tan }}-E_{\text {tan }}^{i}=0
$$

Arus yang terinduksi pada badan penghantar dapat ditulis sebagai superposisi total arus karakteristik. [5]

$J=\sum_{n} \alpha_{n} J_{n}$

$a_{n}=\frac{V_{n}^{i}}{1+j \lambda_{n}}$

$J_{n}$ adalah arus eigen, $\lambda_{n}$ adalah nilai eigen dan $V_{n}^{i}$ adalah koefisien eksitasi modal. Total arus juga bergantung pada $\lambda_{n}$. Mode yang meresonansi adalah ketika $\lambda_{n}=0$ dimana pada kondisi tersebut nilai modal significance berada pada nilai maksimum $\left(\mathrm{MS}_{\mathrm{n}}=1\right)$. [5]

\subsection{Perancangan Desain Circular Patch \\ 2.2.1. Spesifikasi}

Spesifikasi antena menjadi bagian yang penting dalam proses perancangannya. Antena yang akan dibuat adalah antena mikrostrip narrowband menggunakan slot di bagian bawah tepi lingkaran dengan spesifikasi:
- Rentang frekuensi

: 2,400 - 2,484 GHz

- $S_{11}$

- VSWR

$: \leq-10 \mathrm{~dB}$

- Gain

$: \leq 2$

- Pola radiasi

$: \geq 2 \mathrm{dBi}$

: directional

\subsubsection{Dimensi Patch}

Konfigurasi peradiasi circular patch hanya terdiri dari parameter jari-jari patch. Perhitungan jari-jari patch menggunakan persamaan (4) [6]:

$a=\frac{\mathrm{F}}{\left\{1+\frac{2 h}{\pi \mathrm{a} \varepsilon_{\mathrm{r}}}\left(\operatorname{In} \frac{\pi \mathrm{F}}{2 h}+1.7726\right)\right\}^{0.5}}$

Nilai dari a didapatkan dengan menggunakan persamaan (5) [6]:

$$
F=\frac{8.791 \times 10^{9}}{f r \sqrt{\varepsilon_{r}}}
$$

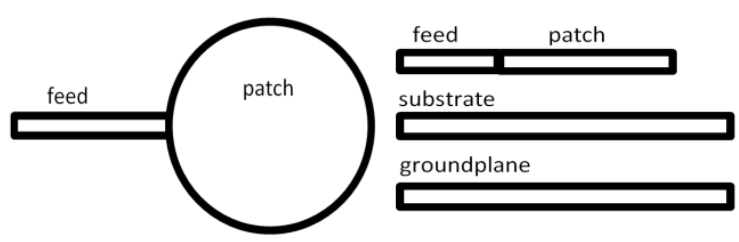

Gambar 1. Antena Mikrostrip Circular Patch

\subsubsection{Dimensi Saluran Pencatu}

Adapun rumus untuk menghitung lebar saluran mikrostrip diberikan oleh persamaan (6) dan (7) [7].

$$
\begin{gathered}
B=\frac{377 \pi}{2 Z o \sqrt{\varepsilon_{r}}} \\
w_{f}=w=\frac{2 d}{\pi}\{B-1-\ln (2 B-1)+ \\
\frac{\varepsilon_{r}-1}{2 \varepsilon_{r}}\left[\ln (B-1)+0,39-\frac{0,61}{\varepsilon_{r}}\right\}
\end{gathered}
$$

\section{Hasil dan Analisa \\ 3.1. Desain CMA Patch A}

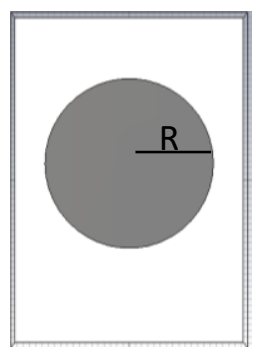

\section{Gambar 2. Desain Patch A dengan CMA}

Gambar 2 merupakan desain patch A atau desain tanpa slot dengan CMA. Berdasarkan Gambar 3 mode pertama $\left(\mathrm{J}_{1}\right)$ dan $\left(\mathrm{J}_{2}\right)$ saling berhimpit memiliki nilai modal 
significance mendekati satu pada frekuensi $3081 \mathrm{MHz}$. Terlihat bahwa mode yang dihasilkan belum berada pada rentang frekuensi yang ditentukan.

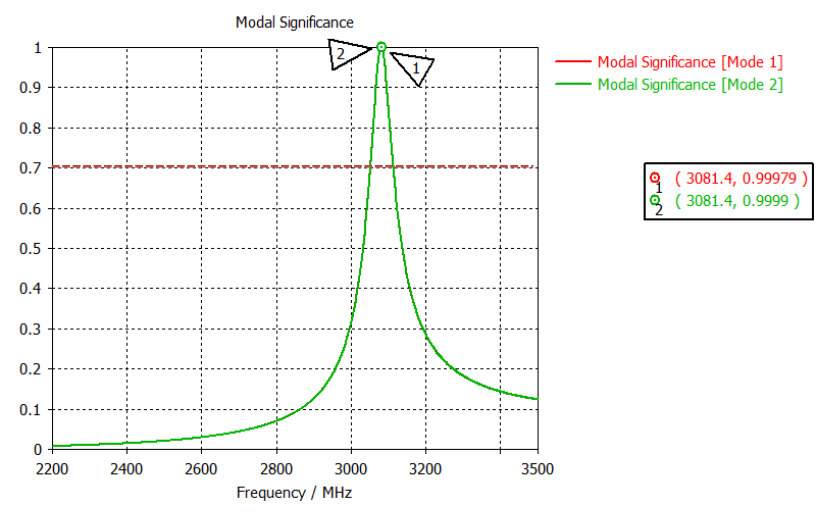

\section{Gambar 3. Grafik Modal Significance Desain Patch A}

\subsection{Desain Antena A (Tanpa Slot)}

Desain antena A pada Gambar 4 sesuai dengan hasil perhitungan menggunakan rumus (4) - (9). Ukuran dimensi antena A terlihat pada Tabel 1. Teknik penyambungan yang digunakan adalah teknik line feed.

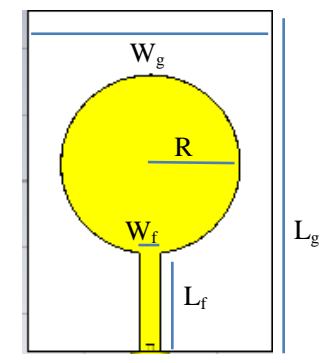

Gambar 4. Desain Antena A

Tabel 1. Ukuran Dimensi Antena A

\begin{tabular}{cccc}
\hline No. & Variabel & Ukuran $(\mathbf{m m})$ & Keterangan \\
\hline 1. & $\mathrm{R}$ & 13,5 & Jari-jari Patch \\
2. & $\mathrm{~L}_{\mathrm{s}}$ & 11,5 & Panjang slot \\
3. & $\mathrm{~L}_{\mathrm{f}}$ & 15 & Panjang saluran transmisi \\
4. & $\mathrm{~W}_{\mathrm{f}}$ & 3 & Lebar saluran transmisi \\
5. & $\mathrm{~W}_{\mathrm{g}}$ & 44 & Lebar groundplane \\
6. & $\mathrm{~L}_{\mathrm{g}}$ & 59 & Panjang groundplane \\
\hline
\end{tabular}

\subsection{Hasil Simulasi}

\subsection{1. $\mathrm{S}_{11}$}

Berdasarkan hasil simulasi pada CST, nilai $S_{11}$ antena dapat diketahui pada grafik $S$-Parameter. Dari Gambar 5 menunjukkan hasil $S_{11}$ sebesar -5,25 dB di frekuensi 3,02 GHz. Grafik menunjukkan bahwa nilai $S_{11}$ belum memenuhi spesifikasi yang ditentukan dan rentang frekuensi yang diperoleh belum sesuai.

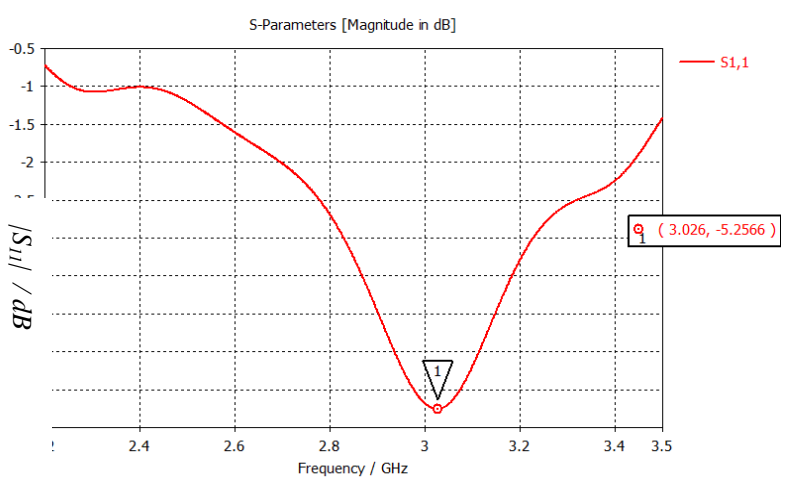

Gambar 5. Hasil $S_{11}$ Antena A

\subsubsection{Gain dan Pola Radiasi}

Gain antena yang dirancang berdasarkan simulasi desain antena A ditunjukkan pada Gambar 6.

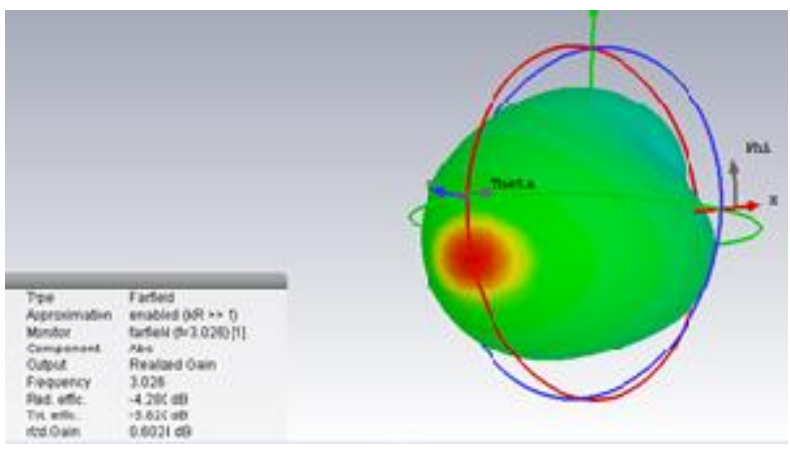

Gambar 6. Gain Desain Antena A

Gambar 6 menunjukkan antena memiliki nilai gain sebesar 0,60 dBi dan dapat diketahui antena memiliki pola radiasi bersifat directional karena hanya mengarah ke satu arah. Nilai gain yang dihasilkan belum sesuai dengan spesifikasi yang ditentukan.

\subsection{Desain CMA Patch B}

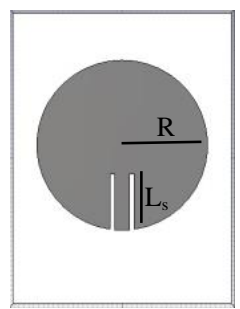

Gambar 7. Desain Patch B dengan CMA

Gambar 7 merupakan desain patch B atau desain penambahan slot dengan CMA. Pada Gambar 8 grafik modal significance desain patch $\mathrm{B}$ menunjukkan adanya perubahan dimana $\mathbf{J}_{1}$ dan $\mathbf{J}_{2}$ terpisah. $\mathrm{J}_{1}$ dan $\mathrm{J}_{2}$ memiliki nilai modal sinificance mendekati satu pada frekuensi $2406 \mathrm{MHz}$ dan $1889 \mathrm{MHz}$. 


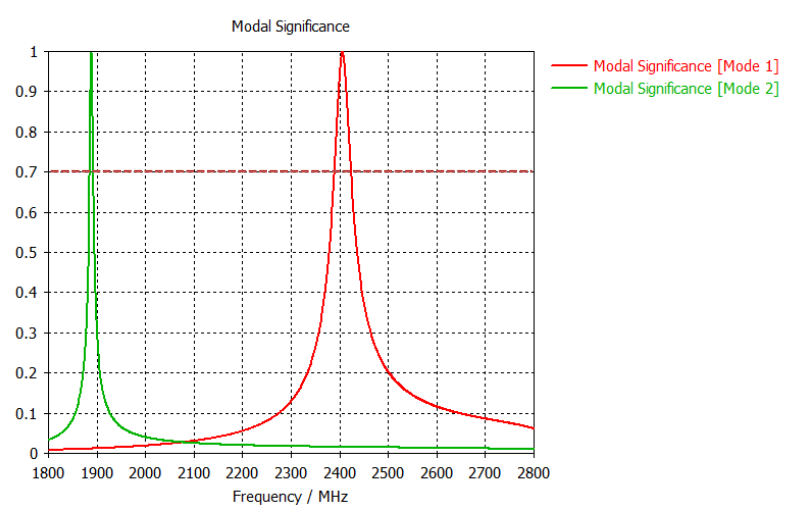

Gambar 8. Gafik Modal Signficance Desain Patch B

\subsection{Desain Antena B (Penambahan Slot)}

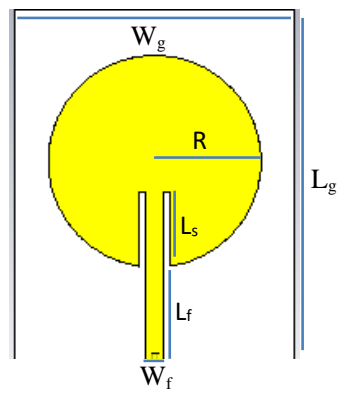

Gambar 9. Desain Antena B

Tabel 2. Ukuran Dimensi Antena B

\begin{tabular}{cccc}
\hline No. & Variabel & Ukuran $(\mathbf{m m})$ & Keterangan \\
\hline 1. & $\mathrm{R}$ & 17,35 & Jari-jari Patch \\
2. & $\mathrm{~L}_{\mathrm{s}}$ & 11,5 & Panjang slot \\
3. & $\mathrm{~L}_{\mathrm{f}}$ & 15 & Panjang saluran transmisi \\
4. & $\mathrm{~W}_{\mathrm{g}}$ & 44 & Lebar groundplane \\
5. & $\mathrm{~L}_{\mathrm{g}}$ & 59 & Panjang groundplane \\
\hline
\end{tabular}

\subsection{Hasil Simulasi}

3.6.1. $\mathrm{S}_{11}$

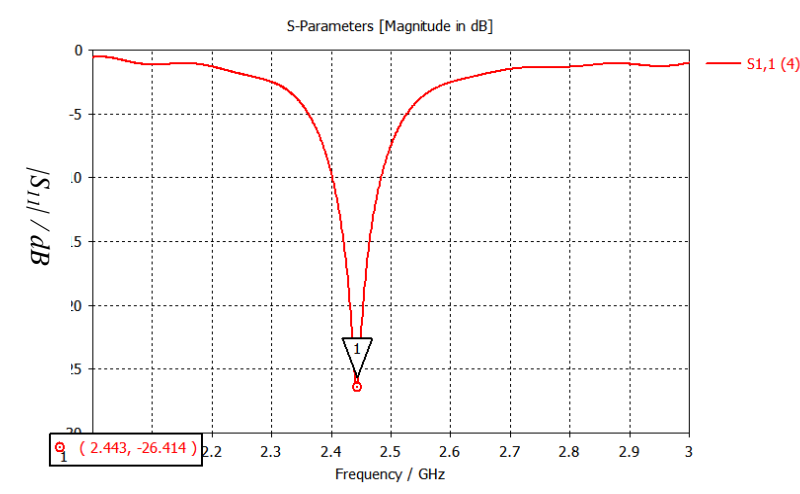

Gambar 10. Hasil $S_{11}$ Desain Antena B

Dari Gambar 10 menunjukkan hasil $S_{11}$ sebesar -26,41 dB pada frekuensi 2,443 GHz. Grafik menunjukkan bahwa nilai $S_{11}$ telah memenuhi spesifikasi yang ditentukan yaitu $\leq-10 \mathrm{~dB}$ dan rentang frekuensi yang diperoleh sudah sesuai, yaitu 2,400 - 2,486 GHz.

\subsubsection{Gain dan Pola Radiasi}

Gain antena yang dirancang berdasarkan simulasi pada rentang frekuensi $2,400-2,486 \mathrm{GHz}$ ditunjukkan pada Gambar 9.

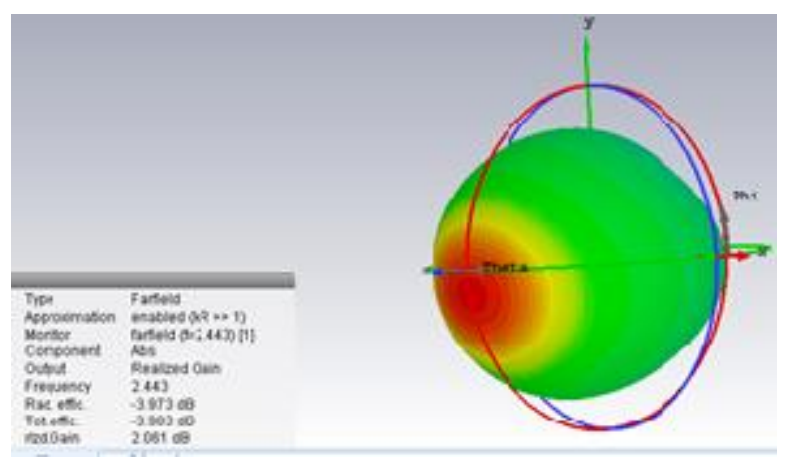

\section{Gambar 11. Gain Desain Antena B}

Gambar 11 menunjukkan antena memiliki nilai gain sebesar 2,06 dBi dan dapat diketahui antena memiliki pola radiasi bersifat directional karena hanya mengarah ke satu arah.

\subsection{Pengukuran Antena}

Parameter kinerja antena yang diujikan yaitu parameter $S_{11}$, VSWR, gain, dan pola radiasi. Hasil pengukuran selanjutnya akan dibandingkan dengan hasil simulasinya. Gambar 12 merupakan bentuk antena yang telah difabrikasi.

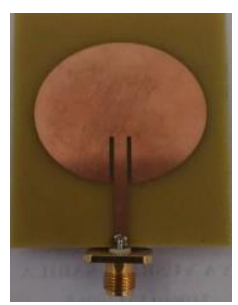

\section{Gambar 12. Antena Fabrikasi}

\subsubsection{Pengukuran $S_{11}$ Antena Mikrostrip}

Berdasarkan hasil simulasi menggunakan CST Microwave Studio 2016 dan pengukuran $S_{11}$ dengan menggunakan Vector Network Analyzer diperoleh gambar berupa grafik dalam satuan decibel (dB) hasil simulasi dan pegukuran seperti pada Gambar 13. Sumbu horizontal menunjukan rentang frekuensi dalam GHz. Sumbu vertikal menunjukan nilai $S_{1 l}$ dalam dB. 


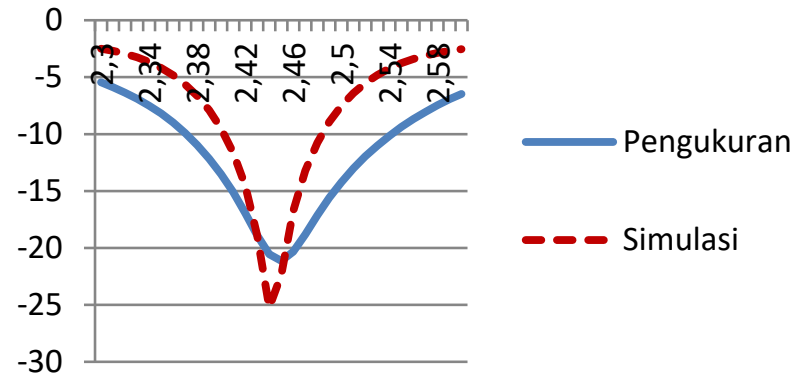

Gambar 13. Hasil Perbandingan Simulasi dan Pengukuran $S_{11}$ Antena Mikrostrip menggunakan Network Analyzer.

Tabel 3. Perbandingan $S_{11}$ antara Hasil Simulasi dengan Pengukuran Antena Mikrostrip

\begin{tabular}{cccc}
\hline Antena & $\begin{array}{c}\text { Nilai } \mathbf{S}_{\mathbf{1 1}} \\
(\mathbf{d B})\end{array}$ & $\begin{array}{c}\text { Frekuensi } \\
(\mathbf{G H z})\end{array}$ & $\begin{array}{c}\mathbf{S}_{\mathbf{1 1}} \text { pada } \\
\text { frekuensi } \\
\mathbf{2 , 4 5} \mathbf{G H z} \\
(\mathbf{d B})\end{array}$ \\
\hline Simulasi & $-26,41$ & 2,443 & $-22,34$ \\
Pengukuran & $-21,13$ & 2,45 & $-21,13$ \\
\hline
\end{tabular}

Gambar 13 dan Tabel 3 menunjukkan perbandingan nilai $S_{11}$ pada hasil simulasi dan pengukuran. Nilai $S_{11}$ pada hasil simulasi memiliki nilai sebesar -26,41 dB pada frekuensi 2,443 $\mathrm{GHz}$, sedangkan pada pengukuran memiliki nilai sebesar $-21,13 \mathrm{~dB}$ pada frekuensi 2,45 $\mathrm{GHz}$. Hal ini menunjukkan bahwa nilai $S_{11}$ dari hasi simulasi trejadi sedikit perbedaan dengan hasil pengukuran, namun telah memenuhi spesifikasi.

\subsubsection{Pengukuran VSWR Antena Mikrostrip}

Berdasarkan Gambar 14 berupa grafik perbandingan VSWR antara hasil simulasi dengan pengukuran menggunakan Vector Network Analyzer. Nilai hasil perbandingan simulasi dan pengukuran ditampilkan pada Tabel 4.

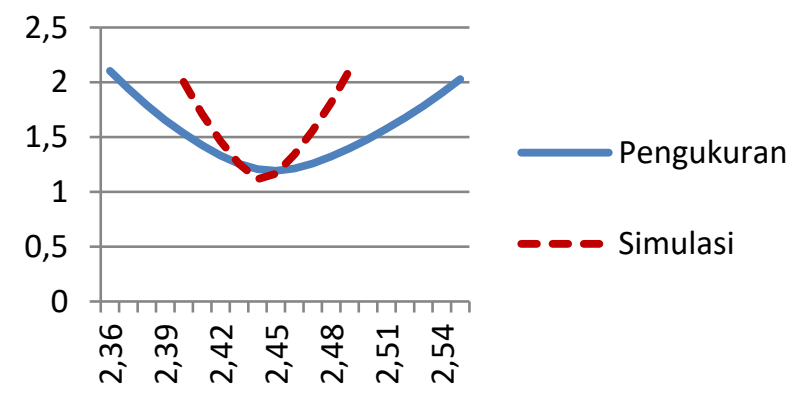

Gambar 14. Hasil Perbandingan Simulasi dan Pengukuran VSWR Antena Mikrostrip menggunakan Network Analyzer.
Tabel 4. Perbandingan VSWR antara Hasil Simulasi dan Pengukuran VSWR Antena Mikrostrip

\begin{tabular}{cccc}
\hline Antena & $\begin{array}{c}\text { Nilai } \\
\text { VSWR }\end{array}$ & $\begin{array}{c}\text { Frekuensi } \\
\text { tengah }(\mathbf{G H z})\end{array}$ & $\begin{array}{c}\text { VSWR pada } \\
\text { frekuensi 2,45 } \\
\mathbf{G H z}\end{array}$ \\
\hline Simulasi & $1: 1,10$ & 2,443 & $1: 1,16$ \\
Pengukuran & $1: 1,19$ & 2,45 & $1: 1,19$ \\
\hline
\end{tabular}

Hasil VSWR pada simulasi bernilai 1,10 pada frekuensi $2,443 \mathrm{GHz}$ sedangkan pada pengukuran antena mempunyai nilai VSWR sebesar 1,19 pada frekuensi resonansi 2,45 GHz. Terlihat perbandingan hasil simulasi dengan pengukuran menunjukan bahwa nilai VSWR mendekati 1:1 dengan rentang frekuensi resonansi yang berbeda. Hal ini ini menunjukan bahwa antena mikrostrip memiliki kinerja yang masih memenuhi spesifikasi VSWR yang diinginkan.

\subsubsection{Lebar Pita Frekuensi Antena Mikrostrip}

Lebar pita frekuensi (bandwidth) dapat diartikan sebagai perbedaan antara frekuensi atas/tertinggi dan frekuensi bawah/terendah berdasarkan VSWR $\leq 1: 2$.

Tabel 5. Perbandingan Lebar Pita Hasil Simulasi dan Pengukuran Antenna Mikrostrip

\begin{tabular}{ccc}
\hline Antena & Lebar pita frekuensi $(\mathbf{M H z})$ & Frekuensi $(\mathrm{GHz})$ \\
\hline Simulasi & 86 & $2,400-2,486$ \\
Pengukuran & 170 & $2,37-2,54$ \\
\hline
\end{tabular}

Data yang digunakan pada pengukuran lebar pita frekuensi ini berdasarkan pada Gambar 14. Tabel 5 menunjukkan hasil simulasi memiliki lebar pita sebesar $86 \mathrm{MHz}$ dan pada hasil pengukuran sebesar $170 \mathrm{MHz}$. Hasil pengukuran antena mikrostrip terlihat dalam memiliki lebar pita yang lebih besar dibandingkan dengan hasil simulasi antena mikrostrip.

\subsubsection{Pengukuran Pola Radiasi}

Diagram polar dari pola radiasi yang telah dinormalisasi pada simulasi dan pengukuran bidang azimut dan elevasi ditunjukan pada Gambar 15 dan Gambar 16. Pada hasil pengukuran, terlihat bahwa pola radiasi antena tersebut sudah mendekati hasil simulasi hanya saja terlihat sedikit kasar apabila dibandingkan dengan hasil simulasinya. 


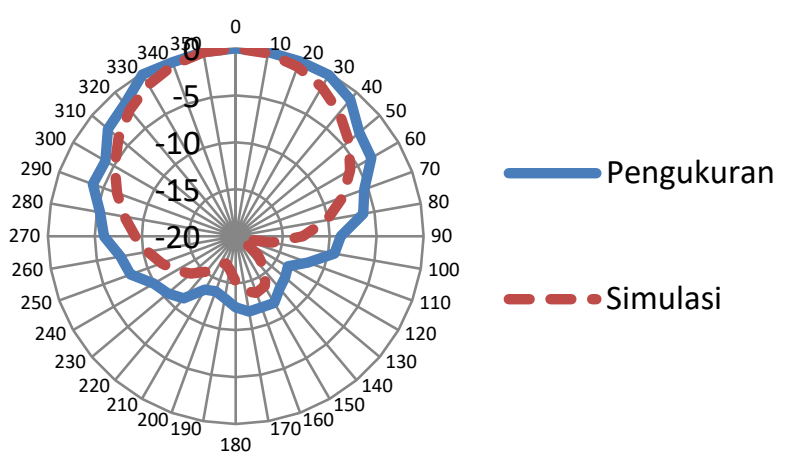

Gambar 15. Hasil Perbandingan Simulasi dan Pengukuran Pola Radiasi Elevasi Antena Mikrostrip

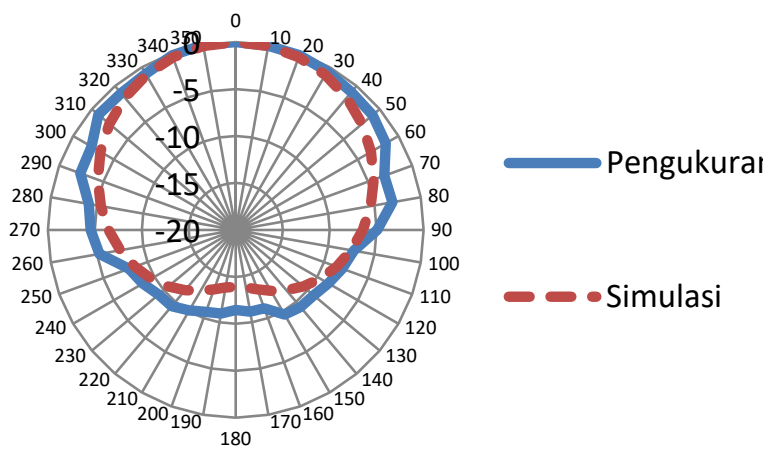

Gambar 16. Hasil Perbandingan Simulasi dan Pengukuran Pola Radiasi Azimuth Antena Mikrostrip

\subsubsection{Pengukuran Gain Antena Mikrostrip}

Pengukuran gain dilakukan di dalam ruangan tanpa gema atau yang disebut Anechoic Chamber. Anechoic Chamber adalah sebuah ruangan yang dirancang untuk meredam gelombang refleksi baik suara atau elektromagnetik. Tabel 6 menunjukan nilai gain dari simulasi dan pengukuran antena mikrostrip.

Tabel 6. Perbandingan Nilai Gain Simulasi dan Pengukuran.

\begin{tabular}{ccc}
\hline Antena & Gain simulasi (dBi) & Gain Pengukuran (dBi) \\
\hline Mikrostrip & 2,06 & 2,15 \\
\hline
\end{tabular}

Hasil nilai gain simulasi dan pengukuran antena mikrostrip diunjukkan pada Tabel 6 . Hasil pengukuran memiliki nilai gain sebesar 2,06 dBi hasil pengukuran memiliki nilai gain sebesar $2,15 \mathrm{dBi}$. Hasil pengukuran menunjukan nilai gain yang lebih tinngi dibandingkan nilai hasil simulasi.

\subsection{Evaluasi Performansi Antena}

Evaluasi performansi antena bertujuan untuk membandingkan hasil simulasi dan hasil pengukuran dengan spesifikasi antena yang dibutuhkan dari antena mikrostrip.

Tabel 7. Perbandingan Hasil Pengukuran dan Spesifikasi Antena Mikrostrip.

\begin{tabular}{cccc}
\hline Besaran & Spesifikasi & Simulasi & Pengukuran \\
\hline $\begin{array}{c}\text { Frekuensi } \\
\text { kerja }\end{array}$ & $2,400-2,484$ & $2,400-2,486$ & $2,37-2,54$ \\
$S_{11}$ & $\leq-10 \mathrm{~dB}$ & $-26,41 \mathrm{~dB}$ & $-21,13 \mathrm{~dB}$ \\
VSWR & $\leq 2$ & 1,10 & 1,19 \\
Gain & $\geq 2 \mathrm{dBi}$ & $2,06 \mathrm{dBi}$ & $2,15 \mathrm{dBi}$ \\
Pola radiasi & Directional & Directional & Directional \\
\hline
\end{tabular}

Perbandingan hasil pengukuran dan simulasi terlihat pada Tabel 7. Perbedaan terletak pada hasil simulasi dengan pengukuran. Hal ini disebabkan oleh faktor fabrikasi antena yang tidak sempurna seperti teknik penyolderan yang kurang rapi sehingga menyebabkan bertambahnya panjang konduktor. Akibatnya, terjadi sedikit perbedaan pada nilai konduktivitas bahan dan resistansi yang tidak sesuai dengan nilai yang ada pada simulasi. Penyebab lainnya adalah ukuran panjang jari-jari patch dan slot saat fabrikasi yang kurang sesuai dengan simulasi., namun frekuensi kerja, $S_{11}$, VSWR, gain, dan pola radiasi pada antena yang sudah difabrikasi memenuhi spesifikasi antena yang ditentukan.

\section{Kesimpulan}

Pada analisis menggunakan teori Characteristic Mode Analysis, hasil grafik modal significance desain patch A terdapat dua mode yang terlihat yaitu $\mathrm{J}_{1}$ dan $\mathrm{J}_{2}$ yang berhimpit di frekuensi $3081 \mathrm{MHz}$ sedangkan hasil grafik modal significance desain patch $\mathrm{B}$ menunjukkan adanya perubahan yaitu dua mode yang semula berhimpit menjadi bergeser dan terpisah. $\mathrm{J}_{1}$ berada pada frekuensi $2406 \mathrm{MHz}$ dan $\mathrm{J}_{2}$ berada pada frekuensi $1889 \mathrm{MHz}$. Dari hasil pengukuran antena mikrostrip yang telah difabrikasi didapatkan beberapa nilai parameter yaitu, $S_{11}$ sebesar 21,13 dB, VSWR 1:1,19, rentang frekuensi 2,37 - 2,54 $\mathrm{GHz}$, pola radiasi directional dan gain sebesar 2,15 dBi. Dari hasil pengukuran, antena yang telah difabrikasi sesuai dengan spesifikasi yang ditentukan. 
TRANSIENT, VOL. 7, NO. 1, MARET 2018, ISSN: 2302-9927, 19

\section{Referensi}

[1]. A. Kamalvand, A. Monajati, M. Ojaroudi, A Low Cost Microstrip Antenna for Wireless Fidelity Application, 2015. Advances in Microelectronic Engineering (AIME). October 2013; Volume 1 Issue 4.

[2]. Otavio P.L, Humberto C.C. Fernandes, Design of Microstrip Antennas Arrays with Circular Patch at Frequency of $2.5 \mathrm{GHz}$, March 2015. Journal of Communications and Information Systems, Vol. 30, No.1.

[3]. Neronzie J, Ali H.R, Rancang Bangun Antena Mikrostrip Patch Circular (2,45 Ghz) dengan Teknik Planar Array sebagai Penguat Sinyal Wi-Fi, Februari 2013. SINGUDA ENSIKO, VOL. 1, NO. 2.
[4]. Hui Li, Student Member, IEEE, YiTan, Buon KiongLau, Senior Member, IEEE, Zhinong Ying, Senior Member, IEEE, and Sailing He, Senior Member, IEEE. Characteristic Mode Based Tradeoff Analysis of Antenna-Chassis Interactions for Multiple Antenna Terminals, February 2012. IEEE Transactions On Antennas And Propagation, Vol. 60, No. 2.

[5]. M. C. Fabres. Systematic design of antennas using the theory of Charateristic Modes. Ph. D. Disertation, Escuela Tecnica Superior De Ingenieros De Telecomicacion, Universidad Politecnica De Valencia; 2007.

[6]. C. A. Balanis, Antenna Theory, 3rd ed. New Jersey: John Wiley \& Sons, 2005.

[7]. D. M. Pozar, Microwave Engineering, 4th ed. John Wiley \& Sons, Inc. 2012 